\title{
The Importance of Financial Literacy towards Entrepreneurship Intention among University Students
}

Noor Lela Ahmad, Rohaila Yusof, Anis Suriati Ahmad, Rosmini Ismail

To Link this Article: http://dx.doi.org/10.6007/IJARBSS/v9-i9/6266

DOI: $10.6007 /$ IJARBSS/v9-i9/6266

Received: 07 June 2019, Revised: 18 July 2019, Accepted: 30 August 2019

Published Online: 08 September 2019

In-Text Citation: (Ahmad, Yusof, Ahmad, \& Ismail, 2019)

To Cite this Article: Ahmad, N. L., Yusof, R., Ahmad, A. S., \& Ismail, R. (2019). The Importance of Financial Literacy towards Entrepreneurship Intention among University Students. International Journal of Academic Research in Business and Social Sciences, 9(9), 18-39.

\section{Copyright: (c) 2019 The Author(s)}

Published by Human Resource Management Academic Research Society (www.hrmars.com)

This article is published under the Creative Commons Attribution (CC BY 4.0) license. Anyone may reproduce, distribute, translate and create derivative works of this article (for both commercial and non-commercial purposes), subject to full attribution to the original publication and authors. The full terms of this license may be seen at: http://creativecommons.org/licences/by/4.0/legalcode

\section{Vol. 9, No. 9, 2019, Pg. 18 - 39}

Full Terms \& Conditions of access and use can be found at http://hrmars.com/index.php/pages/detail/publication-ethics 


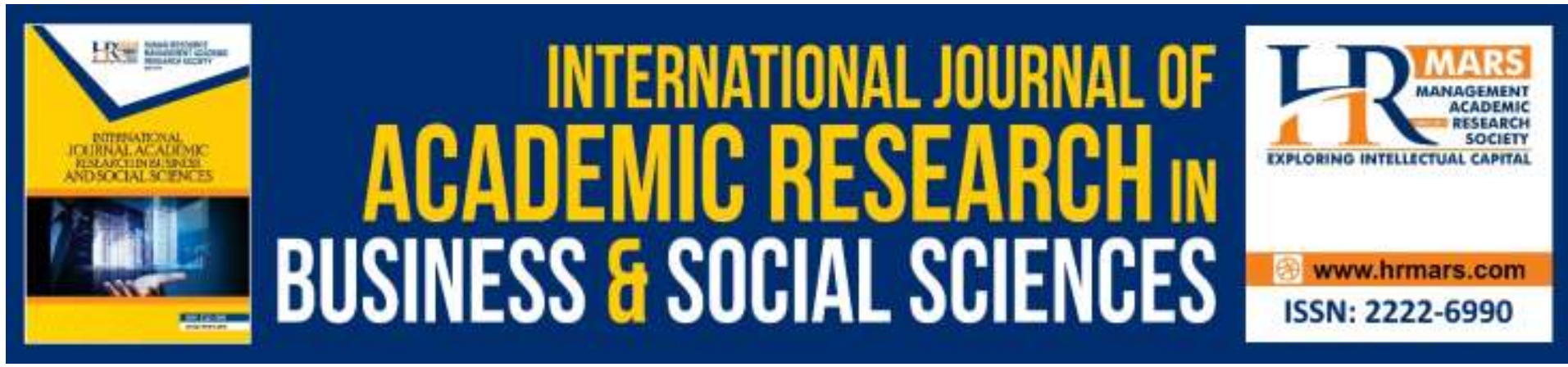

\title{
The Importance of Financial Literacy towards Entrepreneurship Intention among University Students
}

\author{
Noor Lela Ahmad, Rohaila Yusof, Anis Suriati Ahmad, \\ Rosmini Ismail \\ Sultan Idris Education University, Malaysia
}

\begin{abstract}
Issues regarding financial literacy have gained attention and highly debated topics among scholars due to recent global financial scandal has led the government to emphasize on financial education towards its citizen. Emphasizing on financial knowledge is importance to improve nation financial well-being and contribute to country healthy economy. Furthermore, entrepreneurship is seen as one of the many leaps towards a country's growth as it represents an important source of employment, while the youth are the ones responsible of its advancements. The purpose of this paper is to explore the issues regarding financial literacy and it's important as a medium that led to entrepreneurship intention among Malaysian accounting students. This study adopted quantitative survey method to collect data among 238 undergraduates accounting students from four public higher education institutions in Malaysia. The survey instruments includes 20 items that measure the level of financial literacy and 14 items that measure constructs of intention toward entrepreneurship. Descriptive statistic analysis which analyze for frequency, mean and percentage were employed to investigate research questions to obtain the view from research sample. Findings demonstrated that the financial literacy level among undergraduates accounting students are at a moderate level and become a cause of concern and raises serious issues regarding youth capabilities to secure their financial well-being. It has also been observed that financial literacy (financial and management knowledge) lead to increased intention toward entrepreneurship among undergraduates accounting students. The implication of this study is that financial literacy is vital and entrepreneurship dimension should be equipped within future young entrepreneurs. Keywords: Financial literacy, Accounting, Entrepreneurship, Youth, Financial Management.
\end{abstract}

\section{Introduction}

Financial literacy contributes to social values and economical growth and has gained an ultimate amount of attention and discussion from society, experts, government 
agencies as well as policy maker (Huston, 2010). As Malaysia is developing towards a high income country, the need and expenditure of the society also increase along in each phase of their life. However, statistics on financial literacy in Malaysia shows a worrisome number where financial literacy level of individual and the community is low (Dahlia et al., 2009). Previous study on financial literacy among the youth has evidenced lower level of financial literacy (Lusardi et al., 2010; Bartley, 2011; Allgood and Walstad, 2013). This raises the issues that the society needs to have proper financial education to increase their financial knowledge and able to manage their personal finance to make sure they have quality life (Huseyin, 2011; OECD, 2015). Financial literacy is also seen as an important skill as it allows the culture and economy of its citizen and business to grow (Huseyin, 2011; Plakalovic, 2012). With the increase in the cost of living, the ability and knowledge of individuals on financial education should be reconsidered as important to ensure financial well-being of the people.

Nowadays, with the complexity and extensive variety of financial products, youth should prepare themselves with knowledge and skills related to finance planning so that the decisions they taken affect them positively in future (Garg and Singh, 2016). Youth should equipped themselves with financial education, financial management, savings, investments, retirement, will, insurance, loans as well as basic knowledge in personal finance (Garman and Forgue, 2010). According to Plakalovic (2012), among the factors that affects knowledge and financial literacy are school achievements and individual cognitive ability which acts as the key factors that contributes to good financial management. Having such knowledge allows them to make a smarter and wiser financial decision based on the given information which then will help them live free of financial problems. However, as discussed by Noor Azizah et al., (2013), most students encounter their first financial problems when they enter university or college because they have the first task of managing money by their own self. Hence, there is possibility that students may have to face great challenges to take quality financial decisions (Garg and Singh, 2016; Fazli, 2011). This proves that financial literacy is a matter that should be very much focused on especially among youth to ensure the ability of a nation to bring forth many finance literates. It is therefore very important for each student to have the ability and knowledge to manage their own personal finances to enhance their financial well-being (Bartley, 2011).

According to Cole, Paulson and Shastry (2014) and Lusardi and Tufano (2015), youth ability in financial literacy gives room for an improvement to succeed in handling doubtful and subjective matters in finances as he/she is able to make financial decisions wisely and confidently. Having a wide knowledge on finance allows individuals to think rationally and make effective decisions on financial use and management (ANZ Bank, 2008; Van Rooij et al., 2011). Furthermore, a good financial well-being can be achieved and affect future life positively. According to Rubayah et al., (2015) financial knowledge affects individual financial behaviour and personal finance success. This is also pointed out by Atkinson and Messy (2012) in which they said that financial literacy can affect individual important decision making including loan managements, insurance and retirement planning. Other than that, financial literacy guides one's choice to create savings, manage cash management and 
investments (Rooij et al., 2011) as well as spending also need sufficient financial knowledge (Chaterjee, 2013).

Further, Organization for Economic Co-operation and Development OECD (2005) in their report suggests for actions to be taken by individual and society to upgrade their financial knowledge on products, finances, concept and financial risks faced. Such actions should be taken to let youth become more aware and alert of chances and risks of finance in order for them to be able to make wise decisions based on right information, know where to receive help and make affective decisions enhance the growth of finances. In line with this, Bank Negara Malaysia (BNM), have shown concerns on the challenges faced by society especially youth, by forming an organization named 'The Credit Counselling and Debt Management Agency (AKPK, 2016) that contributes to give financial education, financial counselling and debt management program. AKPK help the society by raising the awareness on the rising importance of financial literacy to secure their financial well-being. Through the program assist by AKPK could help the acquisition of financial literacy among the youth and good understanding on financial products and help them to made better financial decisions. Despite the many studies that have explored financial literacy among students, still there is little literature that study links between financial literacy, financial knowledge and entrepreneurship. Thus this paper examines the issues regarding financial literacy and it's important as a medium that led to entrepreneurship intention among Malaysian accounting students.

This article consists of eight key sections. This paper starts with the introduction by first reviewing the concepts of financial literacy. Second parts discuss the literature on entrepreneurship and the importance of financial literacy toward entrepreneurship intention. Third section reviews the methodology of this study. Fourth and fifth section summarizes the finding and discussion section.

\section{Literature Review}

\section{Entrepreneurship Intention through Strengthening of Financial Literacy}

Financial service industry has grown significantly and introduced countless new products and services in order to fulfil user's needs and necessities (Chaterjee, 2013; Herd et al., 2012). The trends set up by world global market showed that the society prefers to purchase financial instruments as one of their investment and it is upon to the customer to select the available products and make the right financial decision (Garg and Singh, 2016; Huseyin, 2011). Moreover, the introduction of many financial instruments for the purpose of savings and loans has lead towards a more complex finance (Chaterjee, 2013). In this matter, financial experts realises the importance of financial literacy to every individual and that understanding basic financial knowledge is a key factor towards a safe and modern financial management in near future (Mandell and Klein, 2009; Cole, Paulson and Shastry, 2014). Thus, each individual has the responsibility in managing his own personal finance and develop an understanding on financial market in order to secure his financial well-being (Agarwalla et al., 2013). Having good financial knowledge is vital and important to be able in making a wise financial decision (Lusardi and Tufano, 2009; Gallery et al., 2011).

Financial literacy contains the knowledge of facts, concepts, principals, as well as technological tools which are the basics of management of income and savings as 
explained by Garman and Forgue (2010). Jump\$tart Coalition Survey Report (2007), stressed that financial literacy is an ability to use knowledge and skills in order to manage one's financial income resources effectively which in turn will give financial benefits a whole lifetime to users. This proves that financial education is a knowledge that is ultimately important to users for them to differentiate different services offered, suppliers and products as a way to retain a safe finance (Wagland and Taylor, 2009; Huseyin, 2011; Rooij et al., 2011). As a response, in terms of its user's safety, financial literacy becomes a guideline for individuals who wish to manage their finance properly (Remund, 2010; Neck and Greene, 2011).

Bernheim (1998) is among one of the earliest scholars to prove that financial knowledge is an important aspect in doing household decisions. Apart from that, other researchers have also proven that financial literacy can affect how individual makes an important financial decision including loan managements (Brown and Graf, 2013), savings, loans and investments (Rooij et al., 2011) as well as personal financing (Chaterjee, 2013; Cole, Paulson and Shastry, 2014). Hence, it is strongly stressed here that financial competence is an important matter that should be taken seriously, especially among youth in order to bring forth young adults with good financial knowledge (Lusardi and Tufano, 2009; Cole, Paulson \& Shastry, 2014). This will result in individual taking quality financial decisions as well as reducing wrong decision making that give negative impacts which may take years for them to solve (Gallery et al., 2011; Huseyin, 2011; Garg and Singh, 2016).

Although Malaysia is categorised as a developing country, Malaysia is however also been listed under one of the countries in which financial literacy level of it citizen is generally low, especially the youths, students and those with low income (Dahlia et al., 2009; Fazli et al., 2007; Rubayah et al., 2015). Previous studies showed that university students have little knowledge on financial literacy (Garg and Singh, 2016; Bartley, 2011; Dahlia et al., 2009; Rooij et al., 2009). The study found that many university students spend their loans or scholarship money before the semester ends. In fact, what is more worrying is that some also uses the money to pay debts (Rubayah et al., 2015). The effects of financial illiteracy may result of poor personal financial management as well as may decrease the academic performance of the students (Hira and Loibl, 2005; Bartley, 2011; Chinen and Endo, 2012).

Further, the impact of having no exposure on financial management, whether at university, college level, or school to any sort of knowledge or skills on how to manage income wisely may affect them for a longer period of time (Ahsan, 2013; Chinen and Endo, 2012; Ahmad and Rhouse, 2016). Therefore, the students are not well prepared to do savings and are challenged by financial spending once they started working alongside with the increase in living cost that is much more expensive than it was back in university (Rubayah et al, 2015; Ahmad and Rhouse, 2016). Universities or other higher education institutions are place where students gain knowledge and encounter experiences on making decisions on their own spending (Azizah et al., 2013). Hence, there is a possibility for students to face many challenges in managing their own finance especially students that come from low income families (Wagland and Taylor, 2009; Agarwall et al., 2013). According to Garman and Forgue (2011) the ability to well manage their spending, savings, loan and investment, youth should be financially literate. It is therefore, a need for youth and every student to be given the 
chance to be exposed to financial education in order for them to have skills, motivation and confidence to apply the knowledge and ability to make effective decisions (Chaterjee, 2013; OECD, 2014).

Apart from that, entrepreneurship has also been as one of the government focus towards youth growth. Entrepreneurship represents an important source of employment and is vital for economic and social growth by creating a successful business (Khaire, 2010; Wise, 2013). For the past 20 years, the world witnessed a positive increase in the number of successful new entrepreneurs, and surprisingly most of them are below 18 years old (Klapper, Lusardi and Panos, 2015). Financial management skills are seen as an important component that every entrepreneurs need which helps towards a good management and give impact towards the productivity and growth of a business (Sucuahi, 2013). Financial competency is listed as one of the critical managerial and financial skill in entrepreneurship (Wise, 2013). Through their business activities always have financial consequences thus entrepreneur must be fully equips with financial knowledge (Oseifuah, 2010).

Previous study revealed that young entrepreneurs are often lack of financial and social knowledge and young entrepreneur have higher failure rates than establish entrepreneur (Khaire, 2010; Baum, Calabrese and Silverman, 2000). On the other hand, lack of entrepreneurship education could deteriorate entrepreneurship culture among Malaysian students. Therefore, Malaysian government should provide support for school, college and university students to involve themselves in entrepreneurship in order for them to contribute to the country's development. More importantly, a variety of programs such as training, seminar and workshops should take place in order to engrave and enhance entrepreneur elements on the students in order to bring forth competitive young entrepreneur (Zaidatol and Habibah, 2004).

Entrepreneurs are also significantly contributing to a country economical activity. Entrepreneur's roles can be nurtured well through a good financial management (Joyce and Gomathi, 2010; Wise 2013). Brown, Berman, Saunders and Bereford (2006) stated that a basic principle to be a succeed entrepreneur is through the strength of the owner's financial literacy. Good business lead towards a healthy competition of the global market (Borodich et al., 2010). On the other hand, weak financial literacy and management, as asserted by Auwal (2015), may contribute towards failures and business close downs. Therefore, a good basic knowledge in financial literacy is very much needed among entrepreneurs and becomes a significant measure towards the success and growth of a business in a competitive state of economy (Huseyin, 2011; Auwal, 2015). Hence, entrepreneurs' weak financial management skills and financial literacy results in negative impact on a business (Drexler, Fischer \& Schoar, 2010). Studdard et al., (2013) argued that one of the most important characteristics of an entrepreneur is to be able to provide buyers with affordable goods and services and at the same time provide a large platform of job opportunities. Thus, entrepreneurship builds bridges between the citizen's ability to purchase the product offered by the entrepreneur. Many changes and development are to occur in the field of entrepreneurship, should lead to more effective business venture and good financial literacy are needed.

Financial crisis, increasing number of debts among the younger generation, increasing rate of bankruptcy of a household proves the need for a research on 
matters regarding financial literacy. Organizations such as European Commission (EC) and OECD (2014) strongly affirmed on the importance of emphasizing financial literacy on younger generations. The current situation demonstrate deficiency and lack of financial literacy, financial behaviour as well as financial management among youth are critical, therefore financial education should be emphasized in higher education institutions. An increase in financial literacy contributes to more informed financial knowledge and should lead an effective financial behaviour and decision. The betterment of financial literacy is seen as a medium towards improvising financial competency and hence influences entrepreneurship start-up intention among undergraduates. A good financial management increases youth financial well-being through good decision making and help their future personal finance (US House Representative and Financial Services, 2009; Jump\$tart Coalition Survey, 2007). This paper maintains that financial literacy is importance and contributes to economic and social growth of a nation. Thus, this paper attempts to determine the level of financial literacy and investigate the influence of financial literacy (management and financial skill) toward entrepreneurship intention among youth by exploring the following research questions:

RQ1: What is the level of financial literacy amongst accounting students?

$\mathrm{RQ2}$ : Does an increase of financial literacy lead to entrepreneurship intention amongst accounting students?

\section{Methodology}

\section{Research Design}

This study was conducted using quantitative research method and adopt questionnaire to collect data as part of initial measurement to obtain view concerning the relation of financial literacy with entrepreneurship intention (Zikmund et al., 2013; Pallant, 2013). Quantitative method can complement research questions by collecting data within the study contexts (Bryman and Bell, 2007). Previous study on financial literacy has also often employed quantitative methodology to test hypothesis developed based on the conceptual framework (Joyce and Gomathi, 2010; Mandel and Klein, 2009). The survey instrument developed in this study was derived from the concepts and reviews of previous literature and consisted of three sections namely demographics profiles, financial literacy dimensions and entrepreneurship intention dimensions. Based on the items of the questionnaire used, researchers are able to observe believes, attitudes and behaviors of targeted groups that is researched on (Sreejesh et al., 2014). Demographics profiles comprised of six items which related to following questions: gender, year of study, university attended, attending entrepreneur course, attending finance course and perception on the importance of financial literacy. Financial literacy dimensions consist of 20 items which assessed student competency related to financial literacy such as saving, spending, credit card, banking, risk, insurance and investment. The third section is entrepreneurship intention dimensions contains of 14 items which examine financial and managerial skill that lead to entrepreneurship intention. 


\section{Sampling Design}

The research population is built from a group of people who meets the requirements of research objectives (Neuman, 2012; Cavana et al., 2000). The sample selection is utilized using purposive judgemental sampling techniques (Cavana et al., 2000; Sreejesh et al., 2014; Zikmund et al., 2013). The sample comprised of undergraduate accounting students in their third and fourth year from four higher education institutions in Malaysia. The selection of the samples mentioned above is due to the fact that based on a study by Chinen and Endo (2012), seniors and business students are more experienced in managing their own money. Out of 300 survey questionnaires were distributed and administered on third and final year students, 238 were completed and usable for data analysis.

\section{Measurement Assessment}

Descriptive statistical analysis consisted of frequency, mean and standard deviation were employed in order to substantiate the research questions. Construct validities are assessed to improvise on the construction of the items by an extant review of literature and verification from three academic experts in the accounting field (Zikmund et al., 2013). A pilot study was conducted on 30 respondents which consist of year three students of a public university. Cronbach's alpha was employed to evaluate the validity and reliability of the financial literacy dimension and entrepreneurship intention dimension. Result from the Cronbach Alpha shows a reading of 0.882 which proves the test to be good and reliable (Pallant, 2013; Hair et al., 2006, p.128).

\section{Data Analysis and Results Student's Profile}

The sample profile is display in Table 1. The sample comprised of 238 undergraduates accounting students from four public HEI in Malaysia. Finding demonstrated that $81.5 \%$ of the respondents were female. Among them, 52.5\% were from Year Three and $47.5 \%$ were from final year. The respondents consist of students of Universiti Pendidikan Sultan Idris (23.1\%), Universiti Utara Malaysia (18.5\%), Universiti Teknologi Mara (42.9\%) and Universiti Sains Malaysia (15.5\%). When asked about if students have ever attended entrepreneur courses, the result shows that $71.4 \%$ of the respondents have attended courses on entrepreneurship in their universities. However, only $40.3 \%$ of them have attended courses on personal management, and as expected $97.5 \%$ of the respondents agreed that financial literacy is an important source of knowledge for them. 
Table 1: Demographical Profiles of Accounting Undergraduates and Data on Entrepreneurship Course and Personal Management Course Taken

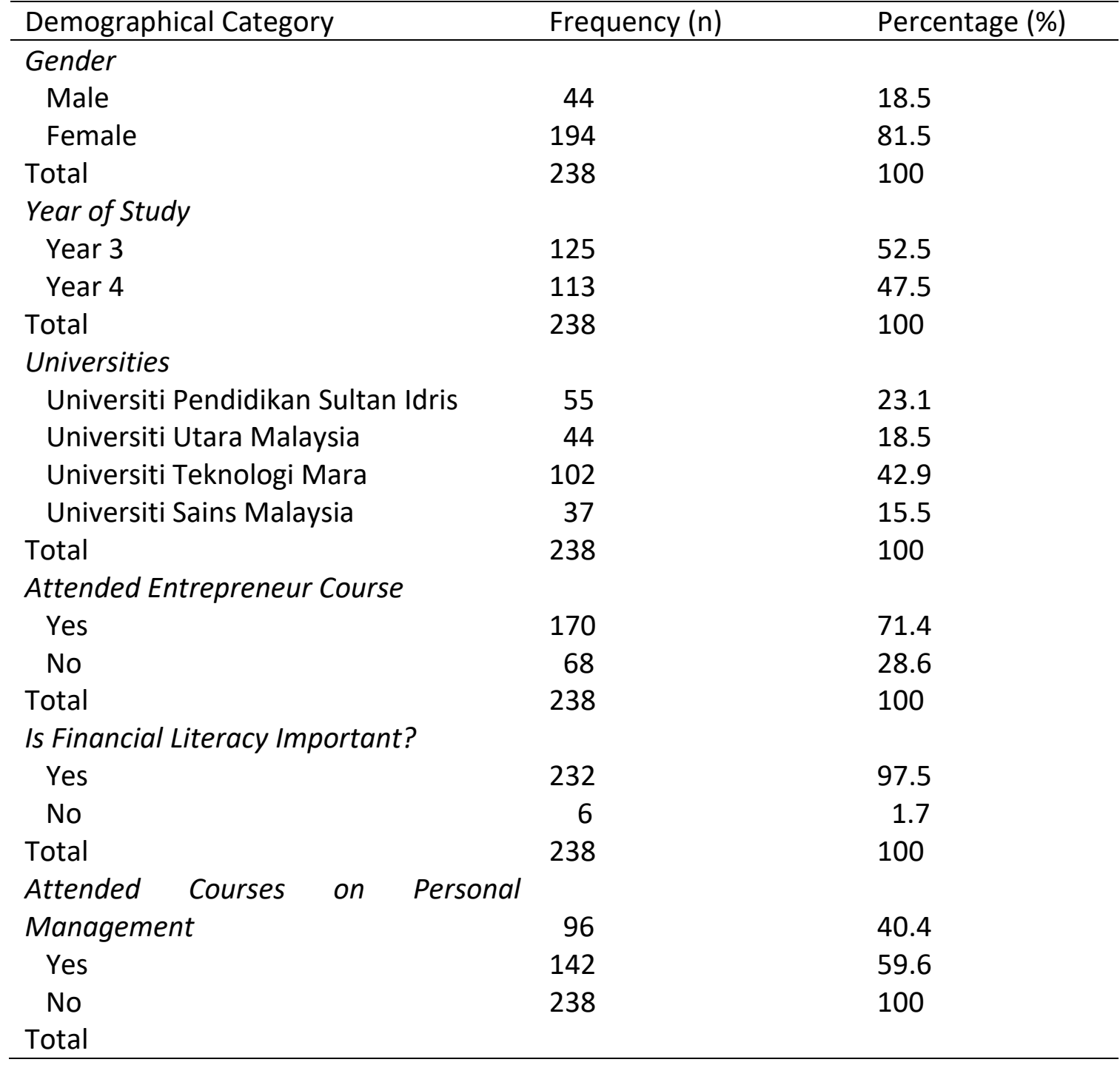

\section{Level of Financial Literacy}

Table 2 demonstrated student's financial literacy level that was analysed based on 20 items of questions to measure the level of their financial knowledge and competency in terms of savings, spending, investments, wills, risk and insurans, credit card, retirement as well as knowledge on financial records. Findings indicated that majority of the students are well educated as they score high in terms of spending as they know that the increase in the price of goods and services decreases the consumer's purchasing power (88.7\%), credit card holders are not allowed to spend without limits (75.6\%) and overspending occurs when savings are used to buy basic everyday needs (77.3\%).

However, it was found that students have moderate level of knowledge on savings. Two of the items were correctly answered by more than half of the respondents where $51.7 \%$ of respondents know that the money saved can raise twice in value after 10 years, and interest rate affects the value of savings in the future 
(80.7\%). Students also agreed that wills are very important for each family (76.5\%). Unfortunately, respondents are not well equipped with knowledge on the importance of insurance as a protection for their future where only $6.3 \%$ of them answered correctly. Students also have a wrong perception of the use of credit cards where only $30.3 \%$ knows that owning a credit card decreases one's purchasing power and $49.6 \%$ knows that money withdrawals using credit card is a high cost money source. Students also have moderate level of knowledge on matters regarding investment and retirement. About $66.8 \%$ of the students believed that EPF contribution alone is not enough to cover out funds after retirement and $80.7 \%$ respondents believed that every family need to have an emergency fund worth the family's three months total spending.

It is interesting to note that an overall analysis conducted to determine students' financial literacy level revealed that the score of respondent's financial literacy was at moderate level which is $62.4 \%$. Scores between 0-20 interpret their level as 'very low'. Scores between 21-56 means 'low' while range between 60-79 illustrates it as 'moderate' and scores between 81-100 demonstrates a 'high' level of knowledge (Chen and Volpe, 1998). Therefore, these data addressed that students should be educated with financial education to increase their financial knowledge so that they will have good attitude toward financial behaviour (Garg and Singh, 2016). Table 2: Respondents Financial Literacy Knowledge

\begin{tabular}{|c|c|c|c|c|}
\hline Item & Answer & Correct & Wrong & $\begin{array}{l}\text { Don't } \\
\text { Know }\end{array}$ \\
\hline \multirow{2}{*}{$\begin{array}{l}\text { 1. Making purchases with debts will decrease one's } \\
\text { purchasing power in the future }\end{array}$} & \multirow[t]{2}{*}{ Correct } & 142 & 79 & 17 \\
\hline & & $59.7 \%$ & $33.2 \%$ & $7.1 \%$ \\
\hline \multirow{2}{*}{$\begin{array}{l}\text { 2. An increase in price decreases one's purchasing } \\
\text { power. }\end{array}$} & \multirow[t]{2}{*}{ Correct } & 211 & 22 & 5 \\
\hline & & $88.7 \%$ & $9.2 \%$ & $2.1 \%$ \\
\hline \multirow[t]{2}{*}{ 3. Balance Sheet shows one's financial status } & \multirow[t]{2}{*}{ Correct } & 173 & 53 & 12 \\
\hline & & $72.7 \%$ & $22.3 \%$ & $5.0 \%$ \\
\hline \multirow[t]{2}{*}{ 4. Card credit holder can spend limitlessly. } & \multirow[t]{2}{*}{ Wrong } & 180 & 55 & 3 \\
\hline & & $75.6 \%$ & $23.1 \%$ & $1.3 \%$ \\
\hline \multirow{2}{*}{$\begin{array}{l}\text { 5. We have overspent once we use savings to buy } \\
\text { daily needs. }\end{array}$} & \multirow[t]{2}{*}{ Correct } & 184 & 41 & 13 \\
\hline & & $77.3 \%$ & $17.2 \%$ & $5.5 \%$ \\
\hline \multirow[t]{2}{*}{ 6. Savings can raise twice in value after ten years. } & \multirow[t]{2}{*}{ Correct } & 123 & 77 & 38 \\
\hline & & $51.7 \%$ & $32.4 \%$ & $16 \%$ \\
\hline \multirow{2}{*}{$\begin{array}{l}\text { 7. Savings are the balance of our income after } \\
\text { putting aside spending money. }\end{array}$} & \multirow[t]{2}{*}{ Wrong } & 35 & 195 & 8 \\
\hline & & $14.7 \%$ & $81.9 \%$ & $3.4 \%$ \\
\hline \multirow[t]{2}{*}{ 8. Interest rate affects savings value in the future. } & \multirow[t]{2}{*}{ Correct } & 192 & 24 & 22 \\
\hline & & $80.7 \%$ & $10.1 \%$ & $9.2 \%$ \\
\hline \multirow{2}{*}{$\begin{array}{l}\text { 9. Income statement shows a family's income and } \\
\text { spending of a certain time. }\end{array}$} & \multirow[t]{2}{*}{ Wrong } & 46 & 168 & 24 \\
\hline & & $19.3 \%$ & $70.6 \%$ & $10.1 \%$ \\
\hline \multirow[t]{2}{*}{ 10.Wills are not needed by family } & \multirow[t]{2}{*}{ Wrong } & 182 & 40 & 16 \\
\hline & & $76.5 \%$ & $16.8 \%$ & $6.7 \%$ \\
\hline \multirow[t]{3}{*}{ 11. Buying insurance is a good form of investment. } & \multirow[t]{2}{*}{ Wrong } & 15 & 203 & 20 \\
\hline & & $6.3 \%$ & $85.3 \%$ & $8.4 \%$ \\
\hline & Wrong & 89 & 91 & 58 \\
\hline
\end{tabular}




\begin{tabular}{|c|c|c|c|c|}
\hline \multirow{4}{*}{$\begin{array}{l}\text { 12.Interest rate from savings account are higher } \\
\text { than the interest rate of a fixed savings. } \\
\text { 13. Life insurance will protects policy holders from } \\
\text { financial burden }\end{array}$} & & $37.4 \%$ & $38.2 \%$ & $24.4 \%$ \\
\hline & Wrong & 46 & 156 & 36 \\
\hline & & $19.3 \%$ & $65.5 \%$ & $15.1 \%$ \\
\hline & Wrong & 72 & 147 & 19 \\
\hline \multirow{2}{*}{$\begin{array}{l}\text { 14.Owning a credit card increases one's } \\
\text { purchasing power }\end{array}$} & & $30.3 \%$ & $61.8 \%$ & $8 \%$ \\
\hline & Wrong & 48 & 122 & 68 \\
\hline \multirow{2}{*}{$\begin{array}{l}\text { 15. One can spend more than } 20 \% \text { of their net } \\
\text { profit to pay their monthly installment. }\end{array}$} & & $20.2 \%$ & $51.3 \%$ & $28.6 \%$ \\
\hline & Wrong & 118 & 77 & 43 \\
\hline \multirow{2}{*}{$\begin{array}{l}\text { 16. Money withdrawal using credit card is a low } \\
\text { cost financial source. }\end{array}$} & & $49.6 \%$ & $32.4 \%$ & 18.1 \\
\hline & Wrong & 130 & 92 & 16 \\
\hline \multirow[t]{2}{*}{ 17. Every form of investment brings profit. } & & $54.6 \%$ & $38.7 \%$ & $6.7 \%$ \\
\hline & Wrong & 63 & 152 & 23 \\
\hline \multirow[t]{2}{*}{ 18. We can make loans to do investment } & & $26.5 \%$ & $63.9 \%$ & $9.7 \%$ \\
\hline & Wrong & 159 & 56 & 23 \\
\hline \multirow{2}{*}{$\begin{array}{l}\text { 19. EPF contribution is sufficient to provide for the } \\
\text { future }\end{array}$} & & $66.8 \%$ & $23.5 \%$ & $9.7 \%$ \\
\hline & Correct & 192 & 33 & 13 \\
\hline $\begin{array}{l}\text { 20. Every family should have emergency fund } \\
\text { savings of at least } 3 \text { months worth of income }\end{array}$ & & $80.7 \%$ & $13.9 \%$ & $5.4 \%$ \\
\hline
\end{tabular}

\section{Entrepreneurship Intention}

Table 3 displays student's perception on the influence of financial literacy towards entrepreneurship intention. The study found that majority of the respondents rated fourteen (14) items at a high level (min, 3.96), which demonstrated that an increase in financial literacy, could lead to more informed and effective financial and managerial skill that motivate student towards entrepreneurship. Table 3 illustrates financial competency that can be obtained if students are financially literate. Entrepreneurship skills are evaluated within two aspects, namely financial and managerial skills. Students rated five (5) highest abilities that can be achieved by future young entrepreneurs if they are financially literate, which are, 'provide skills in calculating profit and net profit' ( $\mathrm{min}, 4.37)$, 'provide skills in updating financial records' (min, 4.17), 'provide skills in financial management' (min, 4.08), 'provide skills in preparing profit and daily spending record' (min, 4.04) and 'provide skills in preparing budgets' ( $\mathrm{min}, 4.04$ ). These data demonstrated that students believed that an increase of financial knowledge and abilities contributes to their entrepreneurship skills. 
Table 3: Student's Entrepreneurship Intention

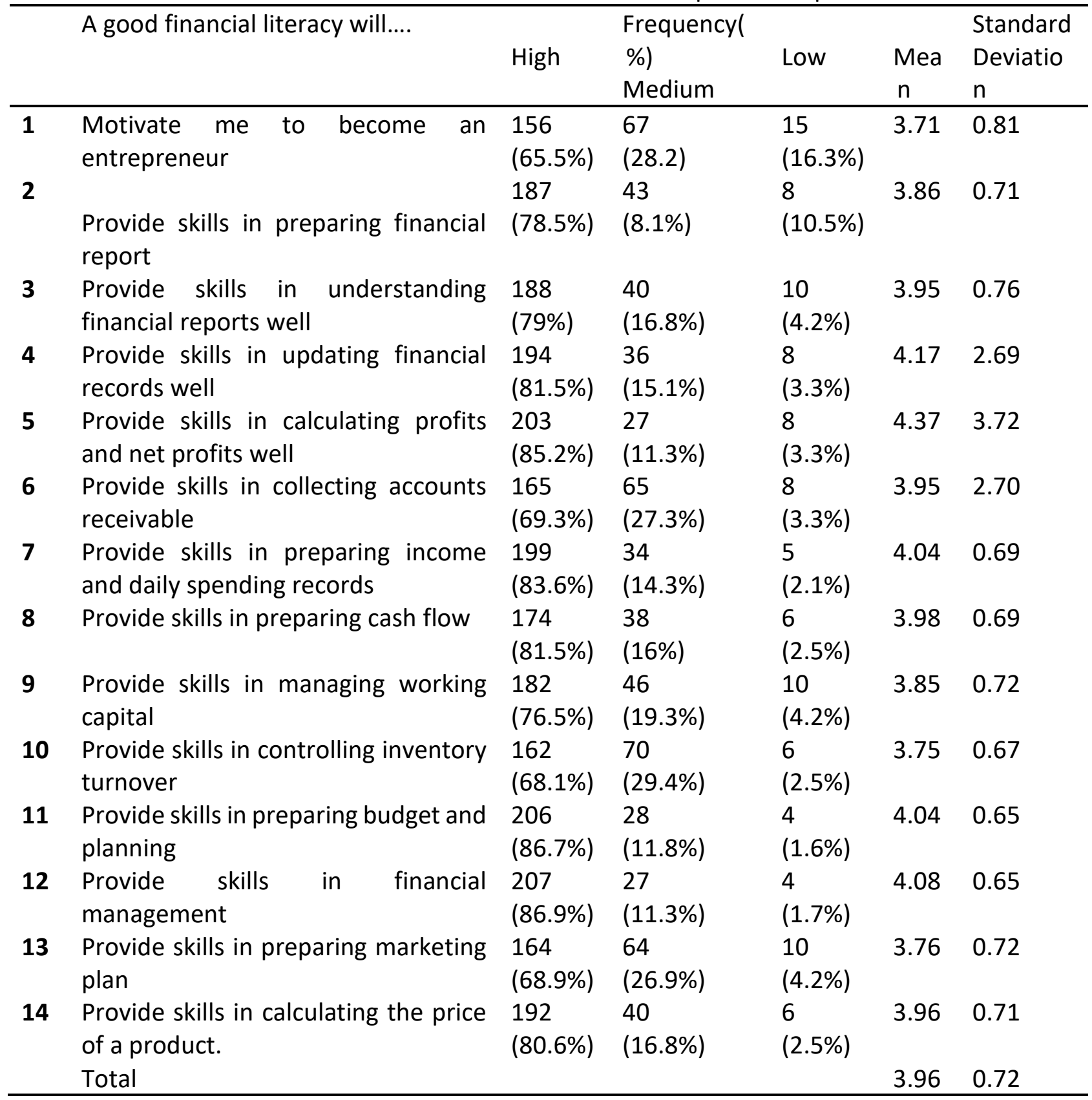

Table 4 summarized five highest entrepreneurship skills according to ranking that can be enhanced by young entrepreneurs if they are a financially literate. From all fourteen entrepreneurship abilities, five highest skills will be an important driver of young entrepreneur's growth if they are financially literates as shown in Table 4. 
Table 4: Ranking of the 'mean' of Entrepreneur's Ability According to its Importance

\begin{tabular}{llll}
\hline & $\begin{array}{l}\text { Entrepreneurship Ability in Financial } \\
\text { Management. }\end{array}$ & Mean & $\begin{array}{l}\text { Standard } \\
\text { Deviation }\end{array}$ \\
\hline $\mathbf{1}$ & $\begin{array}{l}\text { Provide skills in calculating profits and net profits } \\
\text { well. }\end{array}$ & 3.37 & 3.72 \\
$\mathbf{2}$ & $\begin{array}{l}\text { Provide skills in updating financial records. } \\
\mathbf{3}\end{array}$ Provide skills in financial management. & 4.17 & 2.69 \\
$\mathbf{4}$ & $\begin{array}{l}\text { Provide skills in preparing income and daily } \\
\text { spending records }\end{array}$ & 0.65 \\
$\mathbf{5}$ & Provide skills in preparing budgets and planning. 4.04 & 0.69 \\
\hline
\end{tabular}

\section{Discussion}

\section{Financial Literacy and Entrepreneurship Intention}

The study findings suggest that an increase of financial literacy exerts significant positive influence on entrepreneurship intention. Financial literacy is of significant relevant for developing individuals in the aspect of financial knowledge and financial management (Huston, 2010; Huseyin, 2011). Financial literacy can be measured through individual financial knowledge, financial behavior and ability to make informed judgement and effective financial decision (Bucher-Koenen et al., 2016). Study has shown that respondents agreed that being financially literate is an important driver to equip youth with financial knowledge to take quality financial decisions and achieve individual well-being (Atkinson and Messy, 2012; Chaterjee, 2013). Respondents generally have a positive view that by attending financial and entrepreneurship courses demonstrate a positive impact on their financial knowledge. Based on OECD (2014) report, individuals who are financially literate have strong basics on financial concepts. Hence, allows for a smart financial decision making (Huston, 2010). Berheim, Garret and Maki (2001) stated that through financial education showed a positive significant impact on financial behavior.

Based on the data collected from 238 respondents, the results revealed that accounting undergraduate's students have moderate level of financial literacy. However, previous study reported that college and universities student have evidenced of lower level of financial literacy (Lusardi et al., 2010; Lusardi and Mitchell, 2011; Agarwalla et al., 2013). In Malaysia context, the result differs somewhat with the finding from a study done by Dahlia et al., (2009) and Fazli and Teo (2014) which shows that financial knowledge of students and youth in Malaysia is still very low. However, results revealed that an increase of financial literacy among accounting student from third and fourth year might associate with respondents who were from accounting background and due to the fact that seniors are more experienced in managing their own money (Chinen and Endo, 2012),. This data is consistent with results obtained by Barodich et al., (2010) who found that university students' level of financial literacy are at average level.

Although result showed a positive significant increase of financial literacy, the results revealed that majority of the respondents only answered half of the questions right. This makes evidence that students from business background specifically 
accounting students did not report better financial knowledge than those from other programme (Bartley, 2011). This finding highlighted a study conducted by Jump\$tart Coalition Survey 2007 (Mandell, 2006) where it is stated that the younger generations' level of financial literacy is yet at a satisfying level. This implies that care must be utilized to improve financial knowledge of young generation (Wagland and Taylor, 2009; Garg and Singh, 2018). Therefore, Harnisch (2010) suggested that public higher education institutions should stress out on providing courses on financial management through the curriculum to educate students with financial education. By providing financial courses for university students is a good approach towards helping them to gain financial knowledge (Harnisch, 2010). This can be explained through a study by Bucher-Koenen et al., (2016) who found that there is a strong and positive relationship between financial education and the level financial literacy. Meanwhile, Argawalla et al., (2013) also clarified that the higher individual education level is, the higher their financial knowledge will be. Moreover, a study by Bernheim, Garret and Maki (2001) reported that individual who took financial management course in high school tend to has a good financial capabilities.

Financial knowledge is very much needed by every individual as it helps them to make a more effective decision in a certain financial situation they are in (Herd et al., 2012). As stressed by Rooij et al., (2011), Remund (2010) and Atkinson and Messy (2012), individuals with high level of financial literacy have better abilities to understand the basic concepts of finance and deal with financial tasks. Some researchers such as Lusardi and Mitchell (2011), Argawalla et al., (2013) and Rooij et al., (2009) argued that individuals with little financial knowledge have low understanding of the calculation of interest and the use of credit card and less capability to secure his financial well-being. Although financial literacy level of the respondents in this study are at a moderate level, through a deeper and closer observation revealed that they are quite well literate only in five dimension of financial knowledge namely saving, spending, investment, wills and financial reports. Data found that majority of the students aware that an increase in price decreases individual purchasing power. This implies that majority of them are aware that users' purchasing power decreases when price increase from time to time. A large sum of the respondents also aware that interest rate influences savings value in the future. Individuals or users will hence choose financial institutions that provide high interest rate when they choose to save up a sum of their income.

Most of the students also agreed that wills is very important and needed for every family for a save future life. It appears that students have financial knowledge in terms of the savings that need to be done. Majority of the respondents are aware that using savings to buy daily needs means that they have gone over budget. Individuals are facing financial problems if their spending is more than their income. Out of $75.6 \%$ of accounting students studied in this study knows that credit card cannot be spent on over the limit set by the financial institution. This indicated that respondents understand that credit card holders cannot spend over limit. Unfortunately, more than half of the respondents (61.8\%) misunderstood the concept of using a credit card as they think that credit card increases one's purchasing power. This is a misconception that should be fixed and clarified by the educator. It is a critical matter that should be emphasised on in financial education provided for the students. 
Findings of this study are consistent with findings by Bartley (2011) who found that majority of the students scored low in their knowledge on credit cards. According to Bartley (2011), students should have enough knowledge on credit cards as it is part of what has been taught in Mathematics.

Further, the respondents were also asked on questions regarding financial reporting. Findings from this study demonstrated that $72.7 \%$ of the students have good knowledge about Financial Statement whereby financial statement indicates financial status of business. Student knows that Financial Statement report information such as asset, liability, equity and capital of a business. However, majority of respondents (70.6\%) have problems in understanding the use of Income Statement in presenting their income and spending of a certain date. Other than that, when observing on their knowledge on loans and credits, only half of the respondents could identify the fact that purchasing with loads decreases individual purchasing power. This represents that the respondents are not aware of the risks of credit card and loans which gives impact on the future of their financial well-being. Thus Brown and Graf (2013) suggested that financial education related to credit card and loan should be emphasized and focused on in every higher education institution curriculum.

On the other hand, Mandell and Klein (2009) stated that the lack of financial literacy will decrease individual ability to make financial management wisely. In addition, it is found that $65.6 \%$ of the respondents misunderstood on the concept of life insurance, where life insurance is an instrument used to decrease any potential risks in the future, rather than a protection from financial burden for policy holders. This is also been highlighted by Fazli et al., (2007) that insurance is not a form of a good investment as its use is mainly to protect the future. Studies also found that respondents do not understand the basic concept of money savings in financial institutions. This is a concerning matter as only $37.5 \%$ of the respondents knows that interest rate of Fixed Savings are higher than the interest rate of Savings. However, more than half of the respondents (51.7\%) aware that money saved can sum up to twice the price in 10 years. Further, in the aspect of saving up money for the purpose of emergency cases, majority of the respondents (80.7\%) agreed that every family should have savings for at least 3 months in advance. This finding revealed that respondents are well aware of the importance of savings set aside for emergency cases. As Atkinson and Messy (2012) stated that individuals of high financial literacy are prone to commit to savings and pay bills on time.

Knowledge on savings are also seen as important to the users especially among university students who are about to set off to face the reality of life after graduating. Deciding to apply for house and car loans is seen as significant as it is a life need. Respondents were also asked on their monthly instalments. Surprisingly, this study revealed that respondents are not financially literate in this aspect as only $21 \%$ of them aware that users are not to spend more than $20 \%$ of their income net profits to pay their monthly instalments, which is also a critical aspect in a study discussed by Atkinson and Messy (2012). The importance of financial literacy in the aspect of investments is also been focused on in financial management. More than half of the respondents (63.9\%) agreed that users may make loans to invest, which is a misconception. Rather, users should use their savings to invest only when there are amounts of money left after subtracting spending for their daily needs. Only $26.5 \%$ of 
the respondents gave the right answer to this statement. Other than that, more than half of the respondents (54.6\%) know that not all investments guarantee profits in future. In terms of knowledge of retirement, respondents understood that EPF contribution alone is not enough for future needs. Therefore, user should be educated and encouraged to have different kinds of savings other than being highly dependent on employee fund in the future (Brown and Graf, 2013).

Further, entrepreneurship contributes heavily to the wealth of nations and economic growth (Studdard et al., 2013; Wise, 2013). Entrepreneurship involves many disciplines of knowledge, and includes both business and non-business fields (Kuratko, 2004). Younger generations today should be well aware of the fact that entrepreneurship is an important mechanism that encourages new venture and a force for driving employment, innovation and sustainable communities (Sucuahi, 2013; Wise, 2013). Statistics reported that one third of new entrepreneurs are those aged below 30 years old (Kuratko, 2004). This demonstrated an increase in the number of entrepreneurs among the younger generations, which shows a positive growth. However, young entrepreneurs are often lack of sufficient financial competency to make quality financial decision making as stated by Drexler, Fischer \& Schoar, (2010). Thus, according to Oseifuah (2010) in order to be effective youth entrepreneurs need financial knowledge that contributes meaningfully to entrepreneurship skills. Studies attempted to discover that an increase of financial literacy level influence entrepreneurship intention among youth. Therefore, higher educational institutions should play a huge role in developing entrepreneurship skills among university students (Joyce and Gomathi, 2010; Wise, 2013). Unfortunately, entrepreneurship courses or training that been provided in universities is still very low in number and most of the courses are offered only by the faculty of business (Neck and Greene, 2011).

Studies on the roles of financial literacy in influencing and motivate youth toward entrepreneurship attempted to discover that public university students have high entrepreneurship intention. The result revealed that individual skills in financial management can be improved if the individual have good financial literacy (Wise, 2013). Therefore, education on financial literacy should be implemented at university level (Neck and Greene, 2011). Universities should be able to develop financial and entrepreneurship skills among youth and university students as early as possible (Neck and Greene, 2011). Findings demonstrated that good financial literacy is positively interrelated to youth entrepreneurship abilities as a mean to expedite good financial decision. Results display that respondents agreed that financial management skills motivate them to become entrepreneurs. The students also believed that knowledge in finance helps in providing them with skills in preparing financial reports. It is also found that a large number of the respondents agreed that good financial literacy provides them with the skills of interpreting financial reports well. This finding is similar with the study by Klapper, Lusardi and Panos (2015) where their research showed that financial literacy gives a significant relevance on the development of the students to become an entrepreneur. As Neck and Greene (2011) argued that financial knowledge helps entrepreneurs in preventing failure, makes wise decisions and achieve financial stability in life. 
It has been evidenced that majority of the respondents stated that financial management skills helps in giving them the ability to update financial records. As stated by Lusardi and Mitchell (2011), Atkinson and Messy (2012) and Agarwalla et al., (2013) that individual with high financial literacy have an understanding in financial aspects and performs better in saving, numeracy and risk diversification. A large number of the respondents agreed that high financial literacy provides good knowledge in calculating gross profit and net profit. According to Klapper, Lusardi and Panos (2015), financial management skills helps entrepreneurs in the aspect of income, saving, emergency planning and future savings. Moreover, financial literacy also plays an important role when entrepreneur decides to apply for loans, whereby financial literate entrepreneur have the ability to make appropriate decisions and aware the risk associated with financial products (Auwal, 2015; Oseifuah, 2010).

This study reported that on the aspect of knowledge concerning the preparation of financial statement, majority of the respondents agreed that financial management skills helps entrepreneur in preparing for income record and daily spending. Respondents agreed that financial knowledge gives young entrepreneur a lot of knowledge in preparing statement of cash flow. The result also suggested that financial knowledge provides the skills to manage working capital and control inventory turnover. As Oseifuah (2010) argued that young entrepreneur with higher financial literacy contributes to their entrepreneurship skills. Thus, Studdard et al., (2013) proposed that entrepreneur need to have a good financial management as it contributes to a positive outcome in the aspect of income, spending, risks, finance and investment of a business.

In the aspect of budgeting, majority of the respondents agreed that skills in preparing budget come from a good financial literacy. Good financial literacy among students can be implemented through educational curriculum of higher education institutions (Harnisch, 2010; Neck and Greene, 2011). Studdard et al., (2013), emphasized that higher education institutions have the responsibilities to provide financial education to the students. Apart from that, respondents are assured that marketing preparation skills can also be achieved with high financial literacy. The data also recorded respondents agreed that skills in financial management improved entrepreneur in the aspect of calculating the price of a product. This is consistent with the study by Bucher-Keonen et al., (2016), who stated that financial management skills helps entrepreneur in business planning and increasing their capital. Entrepreneur with higher level of financial competency exhibit a good financial management and showed an improvement in business performance (Bruhn and Zia, 2011)

\section{Conclusion}

This study observes on concepts related to financial literacy and the significant influence of financial literacy toward entrepreneurship intention among students in Malaysia higher education institutions. Along with the development of the economy, businesses and the development of community, focus should also be given to entrepreneurs and their skills in financial management. Universities education curriculum should be improved in order to contribute to this skill among students. Studies revealed that good financial literacy among the younger generation is an important element in achieving a brighter tomorrow as youth have to live a longer life 
ahead. Most scholars agree that financial literacy is associated with self beneficial financial behavior (Bernheim, Garret and Maki, 2001; Hilgert, Hogarth and Beverly, 2003; Lusardi and Tufano, 2009). However, Mandell and Klein (2009) noted that financial education may not have immediate impact on financial competency until the knowledge is applied. In general, financial competency is a medium to strengthen financial management skills. Students with higher financial literacy are prone to have skills in managing their money well which hence, bring positive impact on the development of entrepreneurships. Abilities in running a business well require skills in financial management and good financial behaviour among young entrepreneurs. Entrepreneurs should strengthen their financial knowledge in order to achieve success in their business, as entrepreneurs are routinely involved in decision making that have financial consequences (Drexler, Fischer and Schoar, 2010). It is hoped that the findings of this study contributes in knowledge and meaningful information for further improvisation of the educational curriculum in higher education institutions.

\section{Acknowledgement}

This research is funded by Universiti Pendidikan Sultan Idris Research Grant (20170155-106-01).

\section{References}

ANZ (2008) ANZ Survey of Adult Financial Literacy in Australia. Roy Morgan Research BALLENGER, B., 2017.10 Money Mistakes That Everybody Makes. BUSINESS INSIDER. Retrieved from http://articles.businessinsider.com/2017007/news/31605305_1_retirement plan-student-loans-mistakes.

Agarwalla, S. K., Barua, S. K., Jacob, J. \& Varma, J. R. (2013). Financial literacy among working young in urban India. IMA Working Paper. No. 2013-10-02, pp. 1-27.

Ahmad, N. L. \& Rhouse, M. S. (2016). Professional skills of accounting graduates: gap between employer expectations and student needs in accounting curricula. Jurnal Pendidikan Malaysia. Vol 41(1), pp. 7-17.

Allgood, S. and Walstad, W. (2013). Financial literacy and credit card behaviours: a cross-sectional analysis by age, Numeracy, Vol. 6 No. 2, pp. 1-26.

Atkinson, A \& Messy, F. A. (2012).Measuring financial literacy: results of the OECD/international network on financial education (INFE) pilot study. Working Papers on Finance, Insurance and Private Pensions. No. 15, pp. 1-73.

AKPK (2016). Kadar muflis golongan muda di Malaysia merisaukan. https://akpk.org.my/my/pengurusan-kredit.

Barodich, S., Deplazes, S., Kardash, N. \& Kovzik, A. (2010). Comparative analysis of the levels of Financial Literacy among students in the U.S., Belarus and Japan. Journal of Economics and Economic Education Research. Vol 11(3), pp. 71-86.

Bartley, J. (2011). What drives financial literacy among the young? Undergraduate Economic Review. Vol. 7(1), pp 1-15.

Baum, J.A., Calabrese, T., \& Silverman, B.S. (2000). Don't go it alone: Alliance network composition and startups' performance in Canadian biotechnology. Strategic Management Journal. Vol. 21 No. 3, pp. 267-294.

Bernheim, B. D. (1998). Financial illiteracy, Education and Retirement Saving. University of Pennsylvania Press, Philadelphia, pp. 38-68. 
Brown, M. \& R. Graf (2013). Financial Literacy, Household Investment and Household Debt: evidence from Switzerland. Working papers on Finance No. 13/1. Swiss Institute of Banking and Finance.

Brown, R., Berman, S. M., \& Beresford, R. (2006). You owe it to yourself: The financially literate manager. Accounting Forum. Vol 30(2), pp. 197-191.

Bruhn, M., \& Zia, B. (2011). Stimulating managerial capital in emerging markets: the impact of business and financial literacy for young entrepreneurs: World Bank Working Paper, 5642.

Bucher-Koenen, T., Lusardi, A. \& Alessie, R. J. (2016). How financially literate are women? An overview and new insights. GFLEC Working Paper. No 2016-1, pp. 1-37.

Cavana, R. Y., Delahaye, B. L., and Sekaran, U. (2000). Applied Business Research: Quantitative and Qualitative Methods. John Wiley \& Sons. Australia.

Chaterjee, S. (2013). Borrowing Decisions of Credit Constrained Consumers and the Role of Financial Literacy. Economic Bulletin. 33(1), pp. 179-191.

Chinen, K. \& Endo, H. (2012). Effect of attitude and background on personal financial ability: a student survey in the United States. International Journal of Management. 29 (1), pp. 33-45.

Cole, S., Paulson, A. \& Shastry, G. K. (2014). Smart money: the effect of education on financial behavior. Harvard Business School Finance Working Paper. No. 9-71.

Dahlia, I., Rabitah, H. \& Zuraidah, M. I. (2009). A Study on Financial Literacy of Malaysian Degree Students. Cross-cultural Communication. 5(4), pp. 51-59.

Drexler, A., Fischer, G., \& Schoar, A. (2010). Keeping it simple: financial literacy and rules of thumb. Centre for Economic Policy. Research Education Paper. 7994.

Gallery N., Gallery G., \& Brown K., (2011). Financial literacy and pension investment decision. Financial Accountability and Management. 27(3), pp. 286-307.

Garman, E.T. \& Forgue, R. (2010). Personal Finance. Cengage Learning.

Garg, N. and Singh, S. (2018). Financial literacy among the young. International Journal of Social Economics. Vol. 45 No 1, pp.173-186.

Habib Auwal, A. (2015). Entrepreneurship development and financial literacy in Africa. World Journal of Entrepreneurship, Management and Sustaniable Development. Vol. 2 No.3, pp 15-28.

Hair, J. F., Black, W. C., Babin, B. J., Anderson, R. E., and Tatham, R. L. (2006). Multivariate data analysis ( $6^{\text {th }}$ ed). Pearson Educational International. USA.

Harnisch, T. L. (2010). Boosting financial literacy in America: a role for state colleges and universities. Perspectives: American Association of State Colleges and Universities. Fall 2010, pp. 1-23.

Herd, P., Holden, K. \& Su, Y. T. (2012). The links between early-life cognition and schooling and late-life financial knowledge". The Journal of Consumer Affairs. Vol. 46 No.3, pp. 411-435.

Hira, T. \& Loibl, C. (2005). Understanding the impact of employer-provided financial education and workplace satisfaction. Journal of Consumer Affair.Vol. 39 (Summer), pp. 173-194.

Hilgert, M. A., Hogarth, J. M. \& Beverly, S. G. (2003). Household financial management: The connection between knowledge and behavior. Fed Res. Bull. Vol. 89. No. 309 
Huseyin Y. (2011). Improving financial literacy: the US experience. International journal of Business and Social Science. 2(11), pp. 65-72.

Huston, S. J. (2010). Measuring financial literacy. The Journal of Consumer Affairs. Vol. 44 No.2, pp. 296-316.

Joyce, K. H. N. \& Gomathi, S. (2010). The influence of personality traits and demographic factors on social entrepreneurship start up intentions. Journal of Business Ethics. Vol. 95, pp. 259-282.

Jumpstart Coalition for Personal Financial Literacy (2007). National standards in K-12 personal finance education (3rd Edition). Washington DC.

Khaire, M. (2010). Young and no money? Never mind: The material impact of social resources on new venture growth. Organization Science. Vol. 2 No.1, pp. 168185

Klapper, L., Lusardi, A. \& Panos, G. A. (2015). Financial Literacy and Entrepreneurship. GFLE Global Financial Literacy Excellence Center. Working Paper Series. WP 2015-3.

Kuratko, D. (2004). The emergence of entrepreneurship education: Developments, trends, and challenges. Entrepreneurship Theory and Practices, Vol 2 (5), pp. 577-597.

Lusardi, A. \& Tufano, P. (2015). Debt literacy, financial experiences and overindebtness. Journal of Pension Economics and Finance. Vol. 14 No. 4, pp. 332-368.

Lusardi, A. \& Mitchell, O. S. and Curto, V. (2010). Financial literacy among the young. The Journal of Consumer Affair. Vol. 44 No. 2, pp.358-380

Lusardi, A. \& Mitchell O. S, (2011). Financial literacy and retirement planning in the United States. Journal of Pension Economics and Finance. Vol. 14(4), pp. 332368.

Mandell, L. (2006). Financial literacy: if it's so important, why isn't improving?. NFI Policy Brief. No.8, pp. 1-10.

Mandell, L. \& Klein, L. S. (2009). The Impact of Financial Literacy Education on Subsequent Financial Behavior. Journal of Financial Counseling and Planning. 20(1), pp. 15-24.

Sabri, M. F. (2011). Pathways to financial success: Determinants of financial literacy and financial well-being among young adults. PhD Thesis. United States: lowa State University.

Sabri, M. F. \& Juen, T. (2014). The Influence of Financial Literacy, Saving Behaviour, and Financial Management on Retirement Confidence among Women Working in the Malaysian Public Sector. Asian Social Science; Vol. 10, No. 14; 2014 ISSN 1911-2017. E-ISSN 1911-2025.

Sabri, M. F., Masud, J., Paim, L., Othman, M. A. \& Nordin, N. (2007). Kajian keteguhan kewangan di kalangan belia. Institut Penyelidikan Pembangunan Belia Malaysia (IPBBBM).

Ahsan, M. H. (2013). Financial literacy research on undergraduate students in Malaysia: current literature and research opportunities. International Journal of Education and Research. 1(11), pp. 1-12.

Neck, H. \& Greene, P. (2011). Entrepreneurship education: Known worlds and new frontiers. Journal of Small Businesss Management. 49 (1), pp. 55-70. 
Neuman, W. L. (2012). Understanding Research Canada. Prentice Hall Publisher.

Azizah, N. S., Nurfadhilah, A. H., Kumar, R. M. H. M., \& Jafri, M. A. M. S. (2013). Financial Literacy: A Study among The University Students. Interdisciplinary Journal of Contemporary Research Business. Vol 5: No 2. pp. 45-55.

Organization for Economic Co-operation and Development. OECD. (2005). Improving Financial Literacy: Analysis of Issues and Policies. OECD Publishing. Paris.

Organization for Economic Co-operation and Development. OECD. (2014). PISA 2012 technical background, in OECD (ed). PISA 2012 Results: Students and Money: Financial Literacy Skills for the $21^{\text {st }}$ Century. Vol VI, OECD Publishing, Paris, pp. 123-145.

Oseifuah, E. K. (2010). Financial literacy and youth entrepreneurship in South Africa. African Journal of Economic and Management Studies. Vol 1 No. 2, pp. 164182.

Pallant, J. (2013). SPSS Survival Manual: A Step-by-Step Guide to Data Analysis Using IBM SPSS. $6^{\text {th }}$ Edition. Mc Graw Hill. Open University Press.

Plakalovic, N. (2012). Financial literacy and resultant stability of the finance system. Zbornik Radova Ekonoskog Fakulteta Istocno Sarajevo. Vol 6, pp. 135-144.

Remund, D. L. (2010). Financial literacy explication: The case for a clearer definition in an increasingly complex economy. The Journal of Consumer Affairs. Vol. 44, pp. 276-295.

Yakob, R., Janor, H. \& Khamis, N. A. (2015). Tahap Literasi Kewangan Dalam Kalangan Pelajar Universiti Awam: Kajian Di Universiti Kebangsaan Malaysia. Jurnal Personalia Pelajar. 18(1), pp. 97-116.

Studdard, N. L., Dawson, M. \& Jackson, N. L. (2013). Fostering entrepreneurship and building entrepreneurial self-efficacy on primary and secondary education. Versita. DOI: 10.2478/v10212-011-0033-1.

Sucuahi, W. T. (2013). Determinants of financial literacy of micro entrepreneurs in Davao City. International Journal of Accounting Research. Vol 1(1), pp. 24-34.

Sreejesh, S., Mohapatra, S., \& Anusree, M. R. (2014). Introduction to Business Research in Business Research Method. Springer International Publishing.

U.S. House of Representatives, Financial Services Committee. (2009). Regulatory Restructuring: Enhancing Consumer Financial Products Regulation.

Rooij, V. M. C., Lusardi, A. \& Alessie, R. J. (2009). Financial Literacy and Stock Market Participation. Journal of Financial Economics. 101(2), pp. 449-472.

Rooij, V. M. C., Lusardi, A. \& Alessie, R. J. (2011). Financial literacy and retirement planning in the Netherlands. Journal of Economic Psychology.Vol. 32(4), pp. 593-608.

Wagland, S. P. \& Taylor, S. (2009). When it comes to financial literacy, is gender really an issue. The Australian Accounting Business \& Finance Journal. 3(1), pp. 1325.

Wise, S. (2013). The impact of financial literacy on new venture survival. International Journal of Business and Management. Vol. 8 No. 23, pp.30-39

Zaidatol, A. L. P., \& Habibah, E. (2004). Keupayaan Usahawan Bumiputera Melaksanakan Kemahiran Keusahawanan: Satu Kajian Kes. Pertanika J. Soc. Sci. \& Hum. Vol. 12(1), pp. 61-70. 
INTERNATIONAL JOURNAL OF ACADEMIC RESEARCH IN BUSINESS AND SOCIAL SCIENCES Vol. 9, No. 9, September, 2019, E-ISSN: 2222-6990 ๔ 2019 HRMARS

Zikmund, W. G., Babin, B. J., Carr, J. C. \& Griffin, M. (2013). Business Research Methods. Cengage Learning.

\section{Corresponding Author}

Noor Lela Ahmad

Sultan Idris Education University

Email:noor.lela@fpe.upsi.edu.my 